Original Article

\title{
Chemical elements in sediments and in bivalve mollusks from estuarine regions in the south of Bahia State, northeast Brazil
}

\author{
Elementos químicos em sedimentos e em moluscos bivalves de regiões estuarinas do \\ sul do Estado da Bahia, Nordeste do Brasil
}

\section{G. B. M. Santos ${ }^{\mathrm{a}}$ (1) and G. Boehs ${ }^{\mathrm{a}, \mathrm{b} *}$ (1)}

aUniversidade Estadual de Santa Cruz - UESC, Departamento de Ciências Agrárias e Ambientais - DCAA, Programa de Pós-graduação em Ciência Animal, Ilhéus, BA, Brasil

bUniversidade Estadual de Santa Cruz - UESC, Departamento de Ciências Biológicas - DCB, Ilhéus, BA, Brasil

\begin{abstract}
Estuaries receive daily inputs of chemical elements which can impact the quality of water and sediment, as well as the health of biota. In addition to the sediment, bivalve mollusks have been used in the chemical monitoring of these systems. This study investigated the presence and contents of $\mathbf{A s}, \mathbf{B a}, \mathbf{C d}, \mathbf{C o}, \mathbf{C r}, \mathbf{C u}, \mathbf{F e}, \mathbf{M n}, \mathbf{N i}, \mathbf{P b}$ and $\mathbf{Z n}$ in superficial sediment and in bivalves (Crassostrea gasar, C. rhizophorae and Mytella guyanensis) from estuaries in the south / extreme south of Bahia State, northeast Brazil. The samples were evaluated with inductively coupled plasma optical emission spectrometry (ICP-OES, Varian 710). Except for Cd, all other elements were found in the samples, being that Co was exclusive in the sediment. The estuaries equivalent to sampling stations \#1 - Valença, \#2 - Taperoá, \#3 - Ilhéus and \#4 - Belmonte showed levels of metals compatibles with those established by the Brazilian legislation, however, the \#5 - Santa Cruz Cabrália, in addition to the presence of As, presented a high level of $\mathbf{P b}$ and $\mathbf{C u}$ in C. gasar, which was attributed to the impacts of nautical activities in that locality.
\end{abstract}

Keywords: arsenic, heavy metals, lead, mangroves, pollution, preservation.

\begin{abstract}
Resumo
Estuários recebem entradas diárias de elementos químicos, que podem impactar a qualidade de água e do sedimento, assim como a saúde da biota. Além do sedimento, moluscos bivalves têm sido utilizados no monitoramento químico desses sistemas. Neste estudo investigou-se a presença e os teores de As, Ba, $\mathbf{C d}, \mathbf{C o}, \mathbf{C r}, \mathbf{C u}, \mathbf{F e}, \mathbf{M n}, \mathbf{N i}, \mathbf{P b}$ e Zn no sedimento superficial e em bivalves (Crassostrea gasar, C. rhizophorae e Mytella guyanensis) de estuários do sul / extremo sul do estado da Bahia, Nordeste do Brasil. As amostras foram avaliadas por espectrometria de emissão óptica de plasma indutivamente acoplado (ICP-OES, Varian 710). Exceto Cd, todos os demais elementos foram encontrados nas amostras, sendo que Co foi exclusivo no sedimento. Os estuários equivalentes às estações amostrais \#1 - Valença, \#2 - Taperoá, \#3 - Ilhéus e \#4 - Belmonte mostraram níveis de metais compatíveis com os estabelecidos pela legislação brasileira, porém, a \#5 - Santa Cruz Cabrália, além da presença de As, apresentou alto nível de $\mathbf{P b}$ e de $\mathbf{C u}$ em C. gasar, o que foi atribuído aos impactos por atividades náuticas nesse local.
\end{abstract}

Palavras-chave: arsênio, metais pesados, chumbo, manguezais, poluição, preservação.

\section{Introduction}

Estuaries and mangroves receive daily discharges of chemical elements, like heavy metals. This input being the partial result of natural processes, whose substances are usually leached from their place of origin and transported by river waters to their final destination, represented almost always by estuarine sediments (Liu et al., 2020). However, human activities, such as the discharge of industrial and domestic effluents into water bodies, are the most accountable for the increase in chemical levels in these systems (Bakshi et al., 2017; Charry et al., 2018). When a chemical element is released into the aquatic

environment, it usually associates with particulate matter in suspension, being subsequently deposited in the sediment and, through remobilization, the particles of the element return to the water column, then becoming bioavailable (Hatje et al., 2009).

All aquatic invertebrates accumulate, to a lesser or greater degree, chemical elements in their tissues, whether they are essential or not to their metabolism (Rainbow, 2002). When the rate of elimination (by detoxification or excretion) is less than the rate of entry of the chemical agent into the organism, bioaccumulation occurs (DeForest et al.,

*e-mail: guislaboehs@hotmail.com

Received: March 9, 2021 - Accepted: May 27, 2021

This is an Open Access article distributed under the terms of the Creative Commons Attribution License, which permits unrestricted use, distribution, and reproduction in any medium, provided the original work is properly cited. 
2007; Gomes and Sato, 2011). For this reason, in chemical studies and monitoring of estuarine areas, in addition to sediment, biological matrices have also been used. Bivalve mollusks are especially interesting in this context because they have a filtering habit, are generally sessile and usually have a wide geographical distribution (Kimbrough et al., 2008; Melwani et al., 2014). Metals are transferred to bivalve tissues through phytoplankton, which is at the base of the marine food chains (Bragigand et al., 2004).

On the Brazilian coast, sediments have often been used in the analysis of metallic contaminants in aquatic systems (e.g., Onofre et al., 2007; Hatje et al., 2008; Barros and Barbieri, 2012; Mirlean et al., 2012; Kim et al., 2016; Cagnin et al., 2017; Silva et al., 2018). Bivalve mollusks have also been gaining prominence as metal analysis matrices, citing the studies done by: Barros and Barbieri (2012) in Cananeia Estuary (São Paulo, SE-Brazil), using Crassostrea brasiliana (= C. gasar) (Adanson, 1757) (Ostreidae), Lino et al. (2016) in Guanabara Bay and in Ilha Grande (Rio de Janeiro, SE-Brazil), with respective use of Perna perna (Linnaeus, 1758) (Mytilidae) and Nodipecten nodosus (Linnaeus, 1758) (Pectinidae), Campolim et al. (2018) in Santos Bay (São Paulo, SE-Brazil), using P. perna, Barbosa et al. (2019) in Todos os Santos Bay (Bahia, NE-Brazil), using Anomalocardia brasiliana (Gmelin, 1791) (Veneridae), Iphigenia brasiliana (Lamarck, 1818) (Donacidae), Lucina pectinata (Gmelin, 1791) (= Phacoides pectinata)(Lucinidae) and Trachycardium muricatum (Linnaeus, 1758)(Cardiidae), Moreira et al. (2019) in Mucuripe bay (Ceará, NE-Brazil) with Anomalocardia flexuosa (Linnaeus, 1767) (Veneridae) and Crassostrea rhizophorae (Guilding, 1828) (Ostreidae), and Vilhena et al. (2021) in estuaries of the Mocajuba, Tijoca and Pará Rivers (Pará, N-Brazil), using C. gasar and Paxyodon ponderosus Schumacher, 1817 (Hyriidae).

In the present study, we used sediment samples and also the bivalves: oysters $C$. rhizophorae and $C$. gasar, and the mangrove mussel ("sururu") Mytella guyanensis (Lamarck, 1819) (Mytilidae) as metal analysis matrices. Crassostrea rhizophorae, the mangrove oyster, lives generally on aerial roots (rhizomes) and stems of red mangle Rhizophora mangle L., while C. gasar, the bottom oyster, is often attached to rock outcrops, clearly at a lower intertidal level than C. rhizophorae (Boehs et al., 2019). In turn, M. guyanensis lives superficially buried in mangroves, adhering by byssus to underground roots of mangrove plants (Boehs et al., 2010). The three species are economically important throughout the Brazilian coast, mainly as extractive resources for coastal populations.

The estuaries in the south of the state of Bahia, comprising a coastal region of approximately $500 \mathrm{~km}$ of extension, are poorly contemplated in relation to studies on chemical elements, citing the study made by Hatje et al. (2008) in sediments from Camamu Bay, as well as by Cagnin et al. (2017) in mangroves and in the continental shelf region of Abrolhos and by Angeli et al. (2019) in Caravelas estuary, both in the extreme south of the State. In Todos os Santos Bay, central region of the State, there are the works done by Onofre et al. (2007) and Barbosa et al. (2019), analysis of metals in sediment and bivalves, respectively. In the present study we aimed to investigate the presence and content of the elements $\mathrm{As}, \mathrm{Ba}, \mathrm{Cd}, \mathrm{Co}, \mathrm{Cr}, \mathrm{Cu}, \mathrm{Fe}, \mathrm{Mn}, \mathrm{Ni}, \mathrm{Pb}$ and $\mathrm{Zn}$ in estuaries in the south / extreme south of the state of Bahia, between the municipalities of Valença and Santa Cruz Cabrália. The hypothesis of the study is that the mangroves/estuaries in the region are little impacted by chemical elements, given the low industrial activity and other potentially polluting sources in this region.

\section{Material and Methods}

\subsection{Study area}

The study was conducted in estuarine areas between latitudes $13^{\circ} 26^{\prime} \mathrm{S}$ and $15^{\circ} 87^{\prime} \mathrm{S}$, along a coastal stretch of about $450 \mathrm{~km}$ in length (Figure 1 ). This region, which comprises the south/extreme south coast of the Bahia State, northeastern Brazil, is characterized by the presence of numerous estuaries and extensive mangroves, whose forests are predominantly constituted by the red mangrove Rhizophora mangle (Brasil, 2018). The region has an Af type climate in the Köppen classification (humid tropical climate, without a dry season, with an average temperature of the warmest month exceeding $18{ }^{\circ} \mathrm{C}$ and total rainfall in the driest month exceeding $60 \mathrm{~mm}$ ). This coast is also defined by the cocoa culture (mainly in Ilhéus and Belmonte counties) and by the extraction of fishing resources, as well as for beach tourism. Several stretches are protected by Environmental Protection Areas (EPAs), such as the Guaibim and Caminhos da Boa Esperança in municipalities of Valença and Taperoá, the Lagoa Encantada/Rio Almada, in Ilhéus and the Coroa Vermelha, which covers part of the coast of Santa Cruz Cabrália. According to Brasil (2018), these conservation units are primarily responsible for protecting biological diversity and ensuring the sustainability of natural resources in coastal areas, including estuaries and mangroves.

\subsection{Field methodology}

Sampling was carried out in December 2018 in five estuaries (\#1- Valença, \#2 - Taperoá, \#3 - Ilhéus, \#4 - Belmonte and \#5 - Santa Cruz Cabrália) (Figure 1). The collects of sediment and of biological material was previously authorized by the Chico Mendes Institute for Biodiversity and Conservation - ICMBio, Brazil, License number 20912-6. Manual samples of surface sediment were obtained at each estuary, with three repetitions. With regard to bivalves, were captured 15 to 30 specimens / species / estuary, being that $C$. rhizophorae was collected from the aerial roots and trunks of the red mangrove $R$. mangle, $M$. guyanensis in the sediment among the mangrove trees (where sediment samples were also obtained) and C. gasar in artificial substrate in an area of pier, close to the ground. This last bivalve was collected only at \#5, as the only analysis matrix at that place. Sediment and bivalves were packed in properly labeled plastic bags and transported in polystyrene boxes with ice to the laboratory.

\subsection{Laboratory processing}

Sub-samples of sediment were separated, in triplicate, which were dried in an oven at $65^{\circ} \mathrm{C}$ until constant weight, after which the sediment was macerated, sieved and stored in plastic tubes, at room temperature. Nitric acid $\left(\mathrm{HNO}_{3}\right)$ 

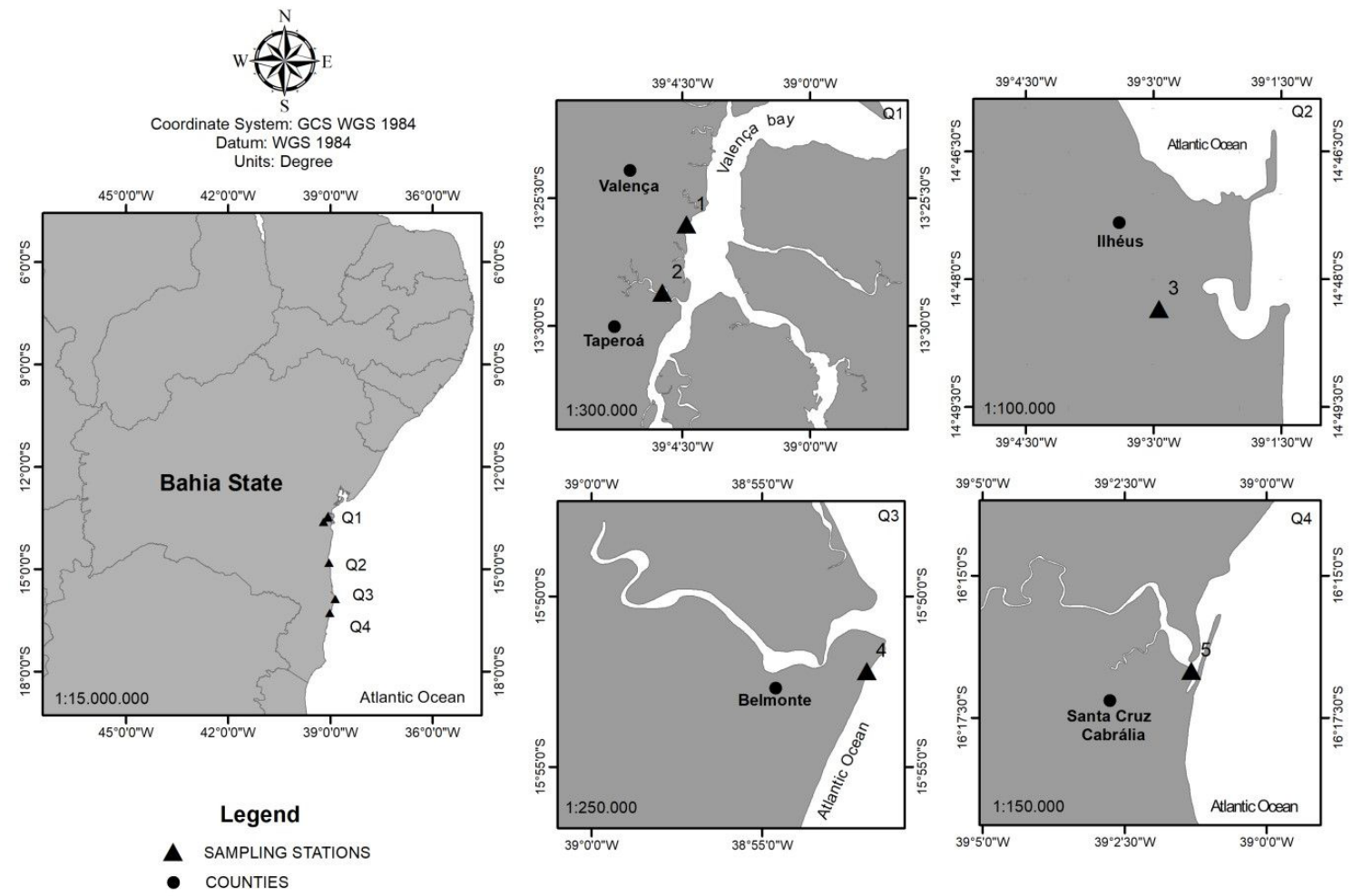

- COUNTIES

Figure 1. Map of the region indicating the sampling stations and counties, where Q1-Q4 define details of each sampling station.

$10 \%$ was used for 24 hours for the previous decontamination of the tubes. Procedures for processing bivalves included: measurement of animals ( shell height = distance between the umbo and the ventral region; Galtsoff, 1964), removal of the shell, washing the edible part (meat) with Milli-Q water (to remove possible impurities), freezing the samples in a freezer at $-80{ }^{\circ} \mathrm{C}$, lyophilization (FreeZone 4.5 L Labconco) until constant weight, manual crushing with the help of mortar and pistil, screening, and storage in plastic bags at $-20^{\circ} \mathrm{C}$.

The digestion process was based on the protocols of the Environmental Protection Agency (EPA, 1996) and Costa et al. (2009), for sediment and bivalves, respectively. For the determination of the chemical elements in all matrices, an Inductively Coupled Plasma Optical Emission Spectrometer - ICP-OES (Varian 710 - ES) was used. For the validation of the chemical analysis of the elements, was used standard reference material certified by the Environmental Protection Agency (EPA, 1996).

\subsection{Data processing and parameters of Brazilian legislation}

The values of the chemical elements were compared among matrices and among localities through one-way analysis of variance (followed, when convenient, by Tukey's test) or by Kruskal-Wallis test, according to the normality of the data, with use of BioEstat 5.0 software. The data were also analyzed through a Principal Component Analysis - PCA, in the MVSP-Multi-Variate Statistical Package, version 3.22. For this analysis, the data (variables $=$ matrices $/$ localities and cases $=$ chemical elements) were standardized and transformed into $\log (2)$. For all analyzes, a 95\% confidence level ( $\alpha=0.05)$ was used.

As legal parameters for maximum values contained in the matrices for each element, was used the Resolution nr. 420 of the National Environment Council - CONAMA (Brasil, 2009) for soils, as the Decree number 55.871 (Brasil, 1965) and Ordinance number 685 (Brasil, 1999), both from the National Health Surveillance Agency of the Ministry of Health - ANVISA, for food.

\section{Results}

Except for Cd, all the elements investigated (As, Ba, $\mathbf{C d}, \mathbf{C o}, \mathbf{C r}, \mathbf{C u}, \mathbf{F e}, \mathbf{M n}, \mathbf{N i}, \mathbf{P b}$ and $\mathbf{Z n}$ ) were detected in the samples. Co was exclusive in the sediment and this matrix was still characterized by high Fe contents, as well as by expressive values of $\mathbf{B a}, \mathbf{C r}, \mathbf{M n}$ and $\mathbf{Z n}$, the latter, however, in lower levels than those found in bivalves (Tables 1 and 2).

As was found only in \#5 - Santa Cruz Cabrália, whose sampling station was also characterized by high levels of $\mathbf{P b}$ and $\mathbf{C u}$ (Table 1; Figure 2) in C. gasar. Regarding $\mathbf{P b}$, \#5 was the only place where this metal was found in a biological sample, since in other localities (\#1-4) it was found exclusively in the sediment (Tables 1 and 2). With regard to $\mathbf{C u}$, in addition to the high concentration of this metal in C. gasar in \#5 (significantly higher than in other localities), a high content of this metal was also 
Table 1. Means and standard deviation of shell height (between parenthesis, in $\mathrm{cm}$ ), and of chemical element contents (in $\mathrm{mg} \mathrm{kg}^{-1}$, $\mathrm{dry}$ weight) of bivalves from estuaries on the south/extreme south coast of the State of Bahia (NE-Brazil).

\begin{tabular}{|c|c|c|c|c|c|c|c|c|c|}
\hline & \multicolumn{9}{|c|}{ Sampling stations, species and shell height values } \\
\hline & \multicolumn{2}{|c|}{$\# 1$} & \multicolumn{2}{|c|}{$\# 2$} & \multicolumn{2}{|c|}{ \#3 } & \multicolumn{2}{|c|}{$\# 4$} & \multirow{2}{*}{$\frac{\# 5}{\mathrm{Cg}}$} \\
\hline & $\mathbf{C r}$ & Mg & $\mathrm{Cr}$ & Mg & $\mathbf{C r}$ & Mg & $\mathrm{Cr}$ & Mg & \\
\hline & $(5.63 \pm 0.75)$ & $(4.60 \pm 0.48)$ & $(6.53 \pm 1.05)$ & $(4.95 \pm 0.33)$ & $(5.42 \pm 0.74)$ & $(4.97 \pm 0.45)$ & $(9.28 \pm 1.78)$ & $(5.37 \pm 0.93)$ & $(3.77 \pm 0.51)$ \\
\hline As & - & - & - & - & - & - & - & - & $3.22 \pm 0.22$ \\
\hline $\mathrm{Ba}$ & $4.40 \pm 0.00$ & $7.96 \pm 0.01$ & $5.35 \pm 0.29$ & $7.22 \pm 0.57$ & $4.46 \pm 0.26$ & $7.72 \pm 0.48$ & $5.38 \pm 0.07$ & $6.40 \pm 0.03$ & $5.64 \pm 0.68$ \\
\hline $\mathrm{Cr}$ & $3.20 \pm 0.02$ & $4.55 \pm 0.03$ & $3.46 \pm 0.45$ & $4.55 \pm 0.04$ & $3.05 \pm 0.17$ & $5.08 \pm 0.10$ & $3.37 \pm 0.06$ & $4.32 \pm 0.04$ & $3.33 \pm 0.02$ \\
\hline $\mathrm{Cu}$ & $17.39 \pm 0.44$ & $9.93 \pm 0.41$ & $14.7 \pm 0.40$ & $11.14 \pm 2.42$ & $23.6 \pm 1.04$ & $14.6 \pm 1.11$ & $37.2^{*} \pm 0.47$ & $18.19 \pm 0.68$ & $160.2^{*} \pm 2.25$ \\
\hline $\mathrm{Fe}$ & $337 \pm 2.83$ & $\mathbf{1 , 0 5 7} \pm 77.39$ & $403 \pm 2.69$ & $\mathbf{1 , 0 8 5} \pm 15.02$ & $299 \pm 8.37$ & $1,690 \pm 70.84$ & $382 \pm 5.98$ & $\mathbf{1 , 1 3 3} \pm 61.33$ & $522 \pm 29.08$ \\
\hline Mn & $20.46 \pm 0.53$ & $\mathbf{6 4 . 2 4} \pm 1.22$ & $15.32 \pm 0.36$ & $\mathbf{7 1 . 5 6} \pm 0.68$ & $26.08 \pm 0.67$ & $\mathbf{7 8 . 0 2} \pm 6.34$ & $15.91 \pm 0.44$ & $102.54 \pm 4.77$ & $22.77 \pm 0.49$ \\
\hline $\mathrm{Ni}$ & - & $1.92 \pm 0.14$ & - & $3.86 \pm 0.20$ & - & $3.83 \pm 0.55$ & - & $2.71 \pm 0.12$ & - \\
\hline $\mathrm{Pb}$ & - & - & - & - & - & - & - & - & $596.73 \pm 391.52$ \\
\hline $\mathrm{Zn}$ & $\mathbf{1 , 2 0 2 . 1} \pm 13.49$ & $61.6 \pm 1.49$ & $\mathbf{1 , 5 2 8 . 6} \pm 21.04$ & $69.9 \pm 0.33$ & $1,212.2 \pm 39.69$ & $76.4 \pm 5.68$ & $\mathbf{1 , 8 0 1 . 7 \pm 9 . 7 3}$ & $74.4 \pm 0.73$ & $\mathbf{2 , 6 3 1 . 2} \pm 291.35$ \\
\hline
\end{tabular}

Cg: Crassostrea gasar; Cr: Crassostrea rhizophorae; Mg: Mytella guyanensis; \#1: Valença; \#2: Taperoá; \#3: Ilhéus; \#4: Belmonte; \#5: Santa Cruz Cabrália; - not detected; in bold: higher values $(\mathrm{p}<0.05)$ in relation to other $(\mathrm{s})$ bivalve $(\mathrm{s})$; *higher values in relation to other sampling stations.

Table 2. Means and standard deviation (in $\mathrm{mg} \mathrm{kg}^{-1}$, dry weight) of chemical element contents found in sediments in estuaries on the south/ extreme south coast of the State of Bahia (NE-Brazil) and maximum values allowed by CONAMA Resolution number 420 (Brasil, 2009 ).

\begin{tabular}{|c|c|c|c|c|c|}
\hline Chemical Elements/ Stations & $\# 1$ & $\# 2$ & \#3 & $\# 4$ & CONAMA reference ${ }^{*}$ \\
\hline $\mathrm{Ba}$ & $43.4 \pm 2.02$ & $44.27 \pm 1.45$ & $47.3 \pm 3.83$ & $59.43 \pm 9.82$ & 150 \\
\hline Co & $7.12 \pm 0.49$ & $9.47 \pm 0.12$ & $7.15 \pm 0.17$ & $9.59 \pm 0.14$ & 25 \\
\hline $\mathrm{Cr}$ & $56.41 \pm 1.95$ & $63.54 \pm 2.49$ & $37.22 \pm 3.00$ & $40.80 \pm 0.55$ & 75 \\
\hline $\mathrm{Cu}$ & $4.68 \pm 0.34$ & $5.88 \pm 0.38$ & $9.91 \pm 1.00$ & $11.36 \pm 0.27$ & 60 \\
\hline $\mathrm{Fe}$ & $18,851 \pm 1,55$ & $21,992 \pm 517.3$ & $20,628 \pm 1,318$ & $22,604 \pm 2,000$ & $* *$ \\
\hline Mn & $115.01 \pm 3.69$ & $135.06 \pm 4.89$ & $195.3 \pm 15.51$ & $187.82 \pm 4.02$ & $* *$ \\
\hline $\mathrm{Ni}$ & $14.76 \pm 0.64$ & $16.6 \pm 0.65$ & $12.06 \pm 0.58$ & $16.2 \pm 0.29$ & 30 \\
\hline $\mathrm{Pb}$ & $6.97 \pm 1.24$ & $7.53 \pm 2.19$ & $7.90 \pm 4.52$ & $9.42 \pm 3.62$ & 72 \\
\hline $\mathrm{Zn}$ & $53.3 \pm 3.27$ & $68.1 \pm 6.29$ & $74.9 \pm 9.95$ & $68.9 \pm 7.26$ & 300 \\
\hline
\end{tabular}

\#1: Valença; \#2: Taperoá; \#3: Ilhéus; \#4: Belmonte; *maximum allowed values; ${ }^{* *}$ not established.

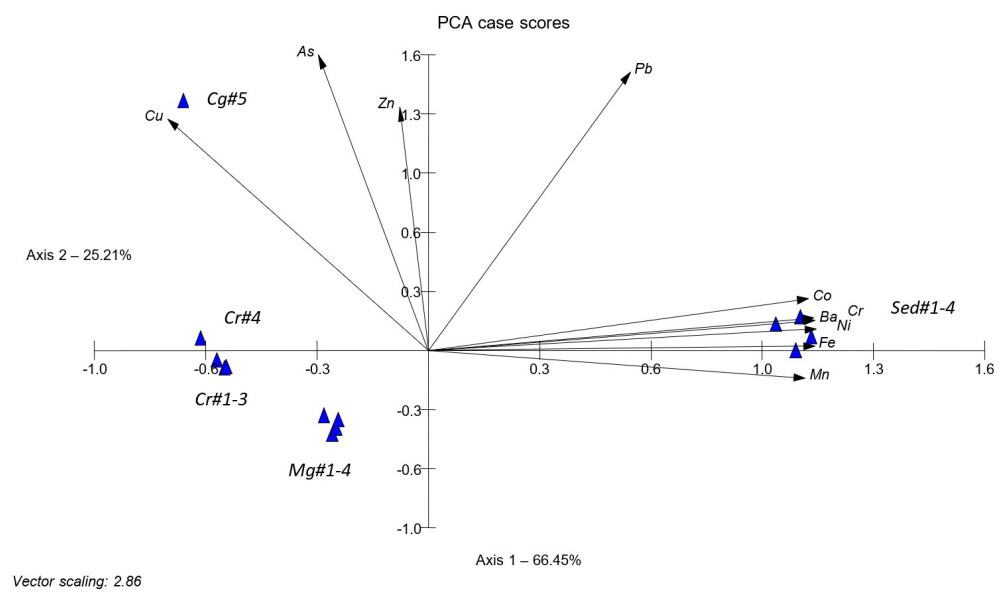

Figure 2. Graphic result of Principal Component Analysis (PCA), showing variables (chemical elements) and observations (analysis matrices and localities) on axes 1 and 2, which together explained $91.66 \%$ of the data variability, with axis 1 being defined mostly by sediment (and associated elements) and also by $\mathrm{Cr}$ and $\mathrm{Mg}$ matrices, while axis 2 was basically defined by matrix $\mathrm{Cg}$ and associated elements. Cr: Crassostrea rhizophorae; Cg: Crassostrea gasar; Mg: Mytella guyanensis; Sed: Sediment; \#1-5: Sample stations. 
found in C. rhizophorae at \#4 - Belmonte, whose the value differed significantly $(\mathrm{p}<0.05)$ from the values found in this species and also in relation to M. guyanensis of the estuaries corresponding to sample stations \#1-3 (Valença, Taperoá and Ilhéus, respectively) (Table 1).

The two species of oysters ( $C$.gasar and $C$. rhizophorae) were characterized, together, by the high content of $\mathbf{Z n}$ (Table 1). The levels of this metal in M. guyanensis were also lower in relation to the sediment, in all places where this species was investigated (\#1-4). In turn, this species was more expressive $(\mathrm{p}<0.05)$ when compared with the oysters, both in the content of Fe and $\mathbf{M n}$. Although there was no statistical difference at the level of $\alpha=0.05$ in relation to the two species of oysters, in M. guyanensis there was also greater expression of the Ba and $\mathbf{C r}$. Furthermore, $M$. guyanensis was exclusive in relation to oysters regarding the occurrence of $\mathbf{N i}$ (Table 1 ).

In general, especially considering sample stations \#1-4, all matrices were consistent with regard to the content of each chemical element, that is, the values of each element were close to each other. This was also evidenced by the graphic result of the principal component analysis (PCA), in which there was a separation among the matrices, with the formation of specific groups of matrices involving the sampling stations \#1-4, being separated only to \#5. The PCA, whose axes 1 and 2 defined more than $90 \%$ of the total variability of the data, also corroborated that the elements $\mathbf{C u}, \mathbf{A s}, \mathbf{P b}$ and $\mathbf{Z n}$ were mainly correlated to the oyster $C$. gasar, at the sampling station \#5 (Santa Cruz Cabrália). In turn, the elements $\mathbf{C o}, \mathbf{B a}, \mathbf{C r}, \mathbf{N i}$, Fe and Mn were strongly associated with sediment in the other sampling stations (\# 1-4), in a negative correlation with biological matrices (Figure 2).

\section{Discussion}

The results of the present study showed that the chemical element levels in the superficial sediment of the mangroves corresponding to the sampling stations \#1-Valença, \#2-Taperoá, \#3-Ilhéus and \#4-Belmonte were compatible with the maximum limits recommended by Resolution CONAMA nr. 420 (Brasil, 2009) with regard to the elements $\mathbf{B a}, \mathbf{C o}, \mathbf{C r}, \mathbf{C u}, \mathbf{N i}, \mathbf{P b}$ and $\mathbf{Z n}$. In this context, comparing all values in dry weight, the levels of $\mathbf{P b}$ (6.97$9.42 \mathrm{mg} \mathrm{kg}^{-1}$ ) in sediment were something similar to the results found in Camamu Bay (Bahia), where Hatje et al. (2008) observed an average of $4.48 \mathrm{mg} \mathrm{kg}^{-1}$. Our values of Pb were also similar to the levels obtained by Onofre et al. (2007) in Todos os Santos Bay (BTS) (Bahia) (6.27 mg kg$\left.{ }^{1}\right)$, but above those verified by Barros and Barbieri (2012) in Cananeia estuary (São Paulo), which observed mean values below $1 \mathrm{mg} \mathrm{kg}^{-1}$. Additionally, Vilhena et al. (2021) observed levels of 4 and $12 \mathrm{mg} \mathrm{kg}^{-1}$ in two estuaries of Pará State, northern Brazil and Kim et al. (2016) found an average of $11.41 \mathrm{mg} \mathrm{kg}^{-1}$ in the SãoVicente estuary, Baixada Santista (São Paulo). The CONAMA legislation (BRASIL, 2009) indicates a maximum of $72 \mathrm{mg} \mathrm{kg}^{-1}$ of $\mathbf{P b}$ for soils to be classified as no contaminated. The levels of $\mathbf{C u}\left(4.68-11.36 \mathrm{mg} \mathrm{kg}^{-1}\right)$ were in alignment with other results found on the Brazilian coast, such as in BTS
(5.55 mg kg-1) (Onofre et al., 2007), Amazon estuary (6.5 $\mathrm{mg} \mathrm{kg}^{-1}$ ) (Silva et al., 2018), Pará State estuaries (4.2 and $7.6 \mathrm{mg} \mathrm{kg}^{-1}$ ) (Vilhena et al., 2021) and in Baixada Santista (8.87 $\mathrm{mg} \mathrm{kg}^{-1}$ ) (Kim et al., 2016). The CONAMA legislation establishes a maximum limit of $60 \mathrm{mg} \mathrm{kg}^{-1}$ for $\mathbf{C u}$ in soils (Brasil, 2009). As for Ba, the aforementioned legislation provides for a maximum of $150 \mathrm{mg} \mathrm{kg}^{-1}$. In our study, the mean values of this element ranged from 43.4 to $59.43 \mathrm{mg} \mathrm{kg}^{-1}$, Hatje et al. (2008) observed an average of $42.4 \mathrm{mg} \mathrm{kg}^{-1}$ in Camamu Bay (Bahia) and Vilhena et al. (2021) found 133 and $210 \mathrm{mg} \mathrm{kg}^{-1}$ in two estuaries in Pará State. Therefore, these last authors found higher values of Ba than those found in the state of Bahia and in extrapolation to that recommended by the Brazilian legislation. The maximum Co limit stipulated by CONAMA is $25 \mathrm{mg} \mathrm{kg}^{-1}$. The average value of this element observed in the Camamu Bay (Hatje et al., 2008) was $1.63 \mathrm{mg} \mathrm{kg}^{-1}$, in the Amazon estuary was $13.3 \mathrm{mg} \mathrm{kg}^{-1}$ (Silva et al., 2018) and in the present study the variation was from 7.12 to $9.59 \mathrm{mg} \mathrm{kg}^{-1}$. The $\mathbf{C r}$ values obtained in this study (37.22$63.54 \mathrm{mg} \mathrm{kg}^{-1}$ ) were below the limit proposed by CONAMA, which is $75 \mathrm{mg} \mathrm{kg}^{-1}$. Even so, our levels were higher than those found in Baixada Santista ( $18.21 \mathrm{mg} \mathrm{kg}^{-1}$ ) (Kim et al., 2016) and in Camamu Bay (4.42 $\mathrm{mg} \mathrm{kg}^{-1}$ ) (Hatje et al., 2008) but were lower than those observed in the Amazon estuary (91.5 $\mathrm{mg} \mathrm{kg}^{-1}$ ) (Silva et al., 2018), whose values went beyond the limits of Brazilian legislation. The last authors related the fact to the dynamics of this element in the environment, with a positive correlation to rainfall and an increase in organic matter in the estuary. $\mathbf{N i}$ is established in the CONAMA resolution with a maximum limit of $30 \mathrm{mg} \mathrm{kg}^{-1}$. In the present study, Ni averages ranging from 12.06 to $16.6 \mathrm{mg} \mathrm{kg}^{-1}$ were obtained, whose values were close to the found by Silva et al. (2018) in an Amazonian estuary (22.3 $\left.\mathrm{mg} \mathrm{kg}^{-1}\right)$, but lower values of Ni were found for BTS (6.07 $\mathrm{mg} \mathrm{kg}^{-1}$ ) (Onofre et al., 2007), Camamu Bay (1.9 $\left.\mathrm{mg} \mathrm{kg}^{-1}\right)$ (Hatje et al., 2008) and in Baixada Santista (7.41 $\mathrm{mg} \mathrm{kg}^{-1}$ ) (Kim et al., 2016). As for Zn, CONAMA establishes the maximum limit of $300 \mathrm{mg} \mathrm{kg}^{-1}$. In the present study, the average values of $\mathbf{Z n}$ in sediment were 53.3 to $74.9 \mathrm{mg} \mathrm{kg}^{-1}$. These values were, however, at least three times higher than those found by Onofre et al. (2007) at BTS (18.27 $\mathrm{mg} \mathrm{kg}^{-1}$ ) and at least four times higher than those observed in Camamu Bay (13.7 $\mathrm{mg} \mathrm{kg}^{-1}$ ) (Hatje et al., 2008), but only slightly above those obtained by Kim et al. (2016) in Baixada Santista (47.68 $\mathrm{mg} \mathrm{kg}^{-1}$ ). The levels of Fe, which varied in this study from 18,851 to $22,604 \mathrm{mg} \mathrm{kg}^{-1}$, were similar to the Fe values in the sediment of the São Vicente estuary (SP), which was $18,893 \mathrm{mg} \mathrm{kg}^{-1}$ (Kim et al., 2016). There is no maximum limit established in Brazilian legislation for this metal. Equally not having a maximum limit established by CONAMA, Mn was at slightly lower levels ( 115.01 to $195.3 \mathrm{mg} \mathrm{kg}^{-1}$ ) in the present study at the average obtained by Kim et al. (2016) (258.9 $\mathrm{mg} \mathrm{kg}^{-1}$ ) on São Vicente estuary (SP).

As for the bivalves, in \# 5-Santa Cruz Cabrália, As was detected in the tissues of $C$. gasar, an element that was not found in the sediment or in the bivalves of the other estuaries. In \#5 there was also a high level of $\mathbf{P b}$ and, although compatible with current Brazilian legislation, a conspicuous $\mathbf{C u}$ content in this oyster. Both C. gasar (\#5) 
and C. rhizophorae (\#1-4) were characterized by high levels of $\mathbf{Z n}$. Mytella guyanensis was a protagonist in terms of $\mathbf{F e}$ and $\mathbf{M n}$ contents in relation to the oysters and was also exclusive in terms of the presence of Ni. The three species were also characterized by excess levels of $\mathbf{C r}$ to those recommended by the Brazilian food legislation (ANVISA). Bivalves were also protagonists in levels of $\mathbf{Z n}$ and $\mathbf{C u}$ in relation to the sediment.

The level of As in C. gasar $\left(0.33 \mathrm{mg} \mathrm{kg}^{-1}\right.$, in wet weight - ww) at \#5 was below the maximum value established by ANVISA (Brasil, 1965, 1999), which is $1 \mathrm{mg} \mathrm{kg}^{-1}$ in ww and this element was found exclusively in Santa Cruz Cabrália. With multiple uses (e.g., in herbicides and insecticides), one of the main uses of As is as a wood preservative (ATSDR, 2007a; Reimann et al., 2009). In addition, there is also the use of As in anti-fouling paints on vessels (Almeida et al., 2007). Samples of oysters from \#5 were collected on a dock for crossing ferries and small fishing and tourism vessels, which may have been the immediate cause of contamination of that oyster by this metalloid. Barbosa et al. (2019) found As levels above those allowed by ANVISA (Table 3) for food in the bivalves: Anomalocardia brasiliana (3.07 $\mathrm{mg} \mathrm{kg}^{-1}$ ), Iphigenia brasiliana (4.23 $\left.\mathrm{mg} \mathrm{kg}^{-1}\right)$, Lucina (Phacoides) pectinata $\left(3.5 \mathrm{mg} \mathrm{kg}^{-1}\right)$ and in Trachycardium muricatum ( $3.05 \mathrm{mg} \mathrm{kg}^{-1}$ ) (all values in ww), in different localities in the Todos os Santos Bay (BTS) (Bahia), therefore higher than those found in Santa Cruz Cabrália and also not compatible with the level allowed by ANVISA, remembering that all the aforementioned bivalves are used in human food. The most expressive values of As observed by Barbosa et al. (2019) were those from bivalves (mainly in $L$. pectinata) collected in areas close to industrial and port activities, which reinforces that the presence of this pollutant is directly related to anthropic impacts. As is a persistent chemical element and it generally reaches the estuarine aquatic environments by fluvial flow, with the major part being deposited in the sediment (Kimbrough et al., 2008). When comparing values in dry weight ( $\mathrm{dw}$ ), other studies carried out on the Brazilian coast confirm levels exceeding $15 \mathrm{mg} \mathrm{kg}^{-1}$ (BRASIL, 2009) of this contaminant in sediments. This is the case of the study carried out by Mirlean et al. (2012) on the continental shelf of Espírito Santo State, however, these authors observed lower levels in the mangrove sediments (average of $9.2 \mathrm{mg} \mathrm{kg}^{-1}, \mathrm{dw}$ ). The authors attributed the conspicuous levels of this element in platform sediments to natural phenomena related to the composition and dynamics of the soils of this region. Cagnin et al. (2017), who investigated the As in the continental shelf of Abrolhos region, southern Bahia, verified values of up to $232.32 \mathrm{mg} \mathrm{kg}^{-1}$ in the surface sediments. In addition to analyzing natural causes as the primary source of this element, these authors considered the influence of gold and iron mining in adjacent areas as a cause of the high values in the region.

Regarding $\mathbf{P b}$ in bivalve tissues, this metal was not detected in \#1-4, however, the high level of this element in the tissues of $C$. gasar in \#5 was evident: $61.82 \mathrm{mg} \mathrm{kg}^{-1}$ in wet weight (ww), whereas the ANVISA legislation (Brasil, 1965,1999 ) provides for a maximum of $2 \mathrm{mg} \mathrm{kg}^{-1}$ in ww, therefore, this limit has been exceeded by at least 30 times in the tissues of this oyster in this estuary. The $\mathbf{P b}$ values in C. gasar in \#5 were also at least 20 times higher than the averages found by Barbosa et al. (2019) in other bivalves of economic interest in BTS (Bahia): $0.11 \mathrm{mg} \mathrm{kg}^{-1}$ in A. brasiliana, $0.13 \mathrm{mg} \mathrm{kg}^{-1}$ in $I$. brasiliana, $0.18 \mathrm{mg} \mathrm{kg}^{-1}$ in T. muricatum and $3.17 \mathrm{mg} \mathrm{kg}^{-1}$ in $L$. pectinata, all values in wet weight. The value of $\mathbf{P b}$ obtained in L. pectinata by these authors also exceeded the maximum allowed by ANVISA (Table 3). In its turn, Campolim et al. (2018) found an average value of $0.38 \mathrm{mg} \mathrm{kg}^{-1}$ (ww) in Perna perna from Santos Bay (São Paulo), compatible with ANVISA legislation, while Lino et al. (2016), curiously, they did not detect this element in P. perna in Guanabara Bay (Rio de Janeiro), which is known to be polluted, nor in Nodipecten nodosus collected in Ilha Grande, also in the state of Rio de Janeiro (Table 3). When comparing dry weight ( $\mathrm{dw}$ ) values in bivalve tissues (for which there are no parameters in Brazilian food legislation), Vilhena et al. (2021) reported $\mathbf{P b}$ averages of $1.85 \mathrm{mg} \mathrm{kg}^{-1}$ in C. gasar from the Mocajuba river in the Pará State, in contrast to the alarming value of $596.73 \mathrm{mg} \mathrm{kg}^{-1}$ found in the present study in C. gasar of Santa Cruz Cabrália (Table 3). According to ATSDR (2007b), Pb is a naturally low-abundant element in the earth's crust, but certain industrial activities and its addition to gasoline have generated increases in this pollutant worldwide in recent decades. In \#5 of the current study, nautical activities may have been the cause of the high levels of $\mathbf{P b}$, since it is used in paints and pigments and in the burning of fossil fuels (e.g., painting boats and supply of gasoline and diesel oil vessels near or in the body of water, with possible leaks and washing of boats). These results in \#5 converge with that observed by Barbosa et al. (2019) in BTS (Bahia), which registered an expressive level of $\mathbf{P b}$ in $L$. pectinata collected near the port and industries. $\mathbf{P b}$ is known to be neurotoxic and carcinogenic for humans (ATSDR, 2007b; Kimbrough et al., 2008).

As for the $\mathbf{C u}$ levels found in the current study, the highest values were also those of \#5-Santa Cruz Cabrália, in C. gasar (16.59 $\mathrm{mg} \mathrm{kg}^{-1}$, in wet weight and $160.2 \mathrm{mg} \mathrm{kg}^{-1}$, in dry weight). In the oyster $C$. rhizophorae of the other localities, the values ranged from 14.7 to $37.2 \mathrm{mg} \mathrm{kg}^{-1}(\mathrm{dw}$ ) (Table 1) and the average, in wet weight, was $2.09 \mathrm{mg} \mathrm{kg}^{-1}$ (Table 3), that is, below that established by ANVISA. The average values of $\mathbf{C u}$ in $M$. guyanensis were also low (9.93 to $18.19 \mathrm{mg} \mathrm{kg}^{-1}$, in dry weight and $2.31 \mathrm{mg}$ $\mathrm{kg}^{-1}$, in wet weight: Tables 1 and 3, respectively). In the intraspecific comparison, C. rhizophorae from \#4 had higher averages ( $p<0.05$ ) of $\mathbf{C u}$ in relation to specimens from \#1-3, but the exact cause of this fact could not be verified. One detail that could be considered is that the samples from this first locality were constituted of animals slightly larger than those from the other locations (see Table 1), however, this aspect would have to be further investigated. Although at high levels, Cu levels in \#5 were below that established by ANVISA legislation, which is $30 \mathrm{mg} \mathrm{kg}^{-1}$. When verifying the values of this metal in bivalves from other places on the Brazilian coast, we find some values that went far beyond the limits of the legislation. For example, Barbosa et al. (2019) found an average of $121.3 \mathrm{mg} \mathrm{kg}^{-1}$ (ww) in L. pectinata, from a region close to the port and industries in BTS (Bahia) and 
Table 3. Comparison of results obtained in the present study with some other studies carried out on the Brazilian coast and values established by ANVISA-Brazil (Decree nr. 55.871 and Ordinance nr. 685; Brasil, 1965, 1999, respectively).

\begin{tabular}{|c|c|c|c|c|c|c|c|c|c|c|c|}
\hline \multirow{3}{*}{$\begin{array}{l}\text { Chemical } \\
\text { Elements }\end{array}$} & \multicolumn{10}{|c|}{ Localities/Matrices } & \multirow{3}{*}{$\begin{array}{c}\text { ANVISA } \\
\text { reference } \\
\text { values }\end{array}$} \\
\hline & \multicolumn{4}{|c|}{ BTS } & \multirow{2}{*}{$\begin{array}{l}\text { GB } \\
\text { Pp }\end{array}$} & \multirow{2}{*}{$\begin{array}{l}\text { IG } \\
\mathrm{Nn}\end{array}$} & \multirow{2}{*}{$\begin{array}{l}\text { BS } \\
\text { Pp }\end{array}$} & \multicolumn{3}{|c|}{ Present Study } & \\
\hline & $\mathbf{A b}$ & Ib & Lp & $\operatorname{Tm}$ & & & & $\mathrm{Cr}$ & $\mathrm{Cg}$ & Mg & \\
\hline As & 3.07 & 4.23 & 3.5 & 3.05 & $*$ & $*$ & $*$ & - & 0.33 & - & 1 \\
\hline $\mathrm{Cr}$ & 0.13 & 0.46 & 0.29 & 0.82 & 2.8 & 2.6 & 0.37 & 0.29 & 0.35 & 0.79 & 0.1 \\
\hline $\mathrm{Cu}$ & 2.63 & 2.48 & 121.3 & 0.43 & 698 & 3.3 & 1.63 & 2.09 & 16.59 & 2.31 & 30 \\
\hline $\mathrm{Fe}$ & $*$ & $*$ & $*$ & $*$ & 197 & 40 & 179.97 & 32.03 & 54.06 & 213.36 & $* *$ \\
\hline Mn & $*$ & $*$ & $*$ & $*$ & 22 & 76 & 2.33 & 1.75 & 2.36 & 13.61 & $* *$ \\
\hline $\mathrm{Ni}$ & $*$ & * & $*$ & * & 2.3 & - & 2.31 & - & - & 0.53 & 5.0 \\
\hline $\mathrm{Pb}$ & 0.11 & 0.13 & 3.17 & 0.18 & - & - & 0.38 & - & 61.82 & - & 2.0 \\
\hline $\mathrm{Zn}$ & 11.15 & 30.2 & 28.97 & 11.15 & 62 & 52 & 27.11 & 129.54 & 272.59 & 12.26 & 50 \\
\hline
\end{tabular}

Average values, in $\mathrm{mg} \mathrm{kg-1}^{-1}$, wet weight. BTS: Baía de Todos os Santos (Barbosa et al., 2019); GB: Guanabara Bay (Lino et al., 2016); IG: Ilha Grande (Lino et al., 2016); BS: Baía de Santos (Campolim et al., 2018); Ab: Anomalocardia brasiliana; Cg: Crassostrea gasar; Cr: Crassostrea rhizophorae; Ib: Iphigenia brasiliana; Lp: Lucina pectinata; Mg: Mytella guyanensis; Nn: Nodipecten nodosus; Pp: Perna perna; Tm: Trachycardium muricatum. -: not detected; *not investigated; ${ }^{* *}$ not established.

Lino et al. (2016), found a value of $698 \mathrm{mg} \mathrm{kg}^{-1}$ (ww) in $P$. perna in Guanabara Bay (Rio de Janeiro). When comparing dry weight values of $\mathbf{C u}$ in C. gasar, Vilhena et al. (2021) observed an average of $75 \mathrm{mg} \mathrm{kg}^{-1}$ in an estuary in the state of Pará, while in \#5 this oyster showed $160.2 \mathrm{mg} \mathrm{kg}^{-1}$. Among the anthropic activities that generate the presence of $\mathbf{C u}$ in the environment, are nautical activities related to the use of this metal as a wood preservative and also in anti-fouling paints (ATSDR, 2004). The high content of $\mathbf{C u}$ in oysters of \#5 is probably related to activity of boats of this locality, mainly used in artisanal fishing in the region. This metal has been used for thousands of years in anti-fouling paints and after the ban of inks containing tributyltin (TBT) worldwide in 2003, manufacturers replaced TBT with $\mathbf{C u}$ (and Zn) as biocides (Almeida et al., 2007). Cu can be toxic to aquatic animals and humans when present at levels above those supported by them, but at trace levels it is essential for the functioning of organisms (ATSDR, 2004). Studies made by Pan and Wang (2009) and by Cai and Wang (2019) showed a correlation of $\mathbf{C u}$ with metallothioneins in bivalves, proteins related to the control and elimination (detoxification) of this metal by these organisms, causing large concentrations to be supported and metabolized by these mollusks.

As for the presence and contents of $\mathbf{Z n}$, M. guyanensis presented about $1 / 4$ of this metal at the maximum value stipulated by ANVISA, which is $50 \mathrm{mg} \mathrm{kg}^{-1}$ (ww). On the other hand, the two species of oysters were prominent as to the occurrence of $\mathbf{Z n}$. In C. rhizophorae, considering the estuaries corresponding to sampling stations \#1-4, an average of $129.54 \mathrm{mg} \mathrm{kg}^{-1}$ (ww) was obtained and consistent (similar) values were found among localities. In C. gasar at \#5, mean $\mathbf{Z n}$ values was $272.59 \mathrm{mg} \mathrm{kg}^{-1}$ (ww), slightly more than the double found in C. rhizophorae, which was probably determined by the characteristics of the place and not by the species of oyster. Despite its low toxicity, nautical activities related to the use of antifouling paints potentially introduce artificially $\mathbf{Z n}$ into the environment (Almeida et al., 2007), which may be one of the reasons for the high concentration of this element in \#5. In other bivalves of economic interest from BTS (Bahia), Barbosa et al. (2019) recorded $\mathbf{Z n}$ levels below 30 mg $\mathrm{kg}^{-1}(\mathrm{ww})$, the same having been recorded for P. perna in the Santos Bay (São Paulo) (Campolim et al., 2018). Lino et al. (2016) obtained mean values of $62 \mathrm{mg} \mathrm{kg}^{-1}$ (ww) for this same species in Guanabara Bay (Rio de Janeiro), while these same authors found $52 \mathrm{mg} \mathrm{kg}^{-1}$ of $\mathbf{Z n}$ in $N$. nodosus from Ilha Grande (RJ) (Table 3). These comparisons allow us to suppose that the levels of $\mathbf{Z n}$ are greatly influenced by the levels of this metal in the environment (water and soil), but that, in addition, some species (such as oysters) have a natural propensity to bioaccumulate this element. Góngora-Gómez et al. (2017) found mean Zn values of $267.42 \mathrm{mg} \mathrm{kg}^{-1}(\mathrm{dw})$ in C. gigas cultivated in the La Pitahaya estuary, Gulf of California (Mexico). Likewise, Vilhena et al. (2021) found an average of $8.017 \mathrm{mg} \mathrm{kg}^{-1}$ in C. gasar from Mocajuba river (Pará, Brazil), while in Paxyodon ponderosus, an untrue oyster (belonging to the family Hyriidae and not Ostreidae), the average content was $184 \mathrm{mg} \mathrm{kg}^{-1}$ (dw) on the Pará river, therefore, at a much lower level than that of C. gasar. The physiological reason why oysters accumulate $\mathbf{Z n}$ in high proportion remains to be investigated, but it is possible that it is related to the detoxification proteins mentioned above.

As for $\mathbf{C r}$, all bivalve samples in this study exceeded the limits established by ANVISA, which is $0.1 \mathrm{mg} \mathrm{kg}^{-1}$ in wet weight. Studies carried out in BTS (Barbosa et al., 2019), as well as in Santos Bay (São Paulo) (Campolim et al., 2018) showed values in order of magnitude similar to ours in other species of bivalves, but Lino et al.. (2016) obtained higher values of $\mathbf{C r}$ in bivalves in the state of Rio de Janeiro (Table 3). In the analysis of the dry weight averages of our study (Table 1), there is a similarity among places and species, with a variation between 3.05 and $5.08 \mathrm{mg} \mathrm{kg}^{-1}$. Góngora-Gómez et al. (2017) observed an average value of $24.97 \mathrm{mg} \mathrm{kg}^{-1}$ (dw) in C. gigas from the Gulf of California 
(Mexico), but did not explain the possible cause of this high value. These authors drew attention to the importance of $\mathbf{C r}$ in glucose tolerance by the human body and that its excess can cause diabetes. Although not exceeding the maximum value of Resolution CONAMA nr. 420 (Brasil, 2009) for $\mathbf{C r}$ in the sediment $\left(75 \mathrm{mg} \mathrm{kg}^{-1}, \mathrm{dw}\right)$, the values obtained in the soil for this study are conspicuous (averages between 37.22 and $63.54 \mathrm{mg} \mathrm{kg}^{-1}$ ) when, for example, compared to estuarine sediments obtained in the Baixada Santista (18.21 $\mathrm{mg} \mathrm{kg}^{-1}$ ) (dw) (Kim et al., 2016). As anthropogenic activities that potentially introduce $\mathbf{C r}$ into the environment (e.g., tanneries and metallurgies) are scarce on the southern coast of the state of Bahia, it is assumed that the presence of this element is related to particularities of the region's soil composition, since the state has the greater reserves of this metal among all Brazilian states (33.53\%) (Lima and Neves, 2016), however, specific and detailed studies regarding the presence of $\mathbf{C r}$ in the state's estuaries are necessary to obtain more precise conclusions.

$\mathbf{N i}$ is included in the observance of ANVISA with maximum levels of $5 \mathrm{mg} \mathrm{kg}^{-1}$ (ww), a limit not reached for P. perna in Guanabara Bay (Lino et al., 2016) and also not for M. guyanensis in present study, the only species in which this metal was recorded, at low levels $\left(0.53 \mathrm{mg} \mathrm{kg}^{-1}\right)$ (ww) (Table 3). Lino et al. (2016) and Campolim et al. (2018) recorded 2.3 and $2.31 \mathrm{mg} \mathrm{kg}^{-1}$ (ww), respectively, in $P$. perna in other Brazilian states. Although it is an essential element in small quantities, exposure to high doses can cause problems with bronchitis and for long-term exposure, cancer (Kimbrough et al., 2008).

The maximum values of $\mathbf{B a}, \mathbf{F e}$ and $\mathbf{M n}$ in food are not established in Brazilian legislation. In the case of $\mathbf{B a}$, in the present study this element was present at low levels in the species investigated. In dry weight, in C. rhizophorae the averages were from 4.4 to $5.38 \mathrm{mg} \mathrm{kg}^{-1}$, in M. guyanensis from 6.40 to $7.96 \mathrm{mg} \mathrm{kg}^{-1}$ and in $C$. gasar $5.64 \mathrm{mg} \mathrm{kg}^{-1}$. Comparing these results to those obtained by Vilhena et al. (2021), these obtained averages of $1.70 \mathrm{mg} \mathrm{kg}^{-1}$ (dw) in C. gasar and $1.286 \mathrm{mg} \mathrm{kg}^{-1}(\mathrm{dw})$ in $P$. ponderosus, therefore, the greatest accumulation of Ba occurred in this last bivalve, a species of fresh water. As for Fe and $\mathbf{M n}$, the high level of these metals in M. guyanensis, when compared to the levels observed in the oysters, drew attention in the current study. Thus, M. guyanensis collected in the same localities where $C$. rhizophorae samples were obtained showed six times higher $\mathbf{F e}$ and eight times higher $\mathbf{M n}$ values in relation to this oyster. In the dry weight comparison, the Fe values obtained for $C$. gasar by Vilhena et al. (2021) were $374 \mathrm{mg} \mathrm{kg}^{-1}$, for $522 \mathrm{mg} \mathrm{kg}^{-1}$ in the same species in our study, as well as for averages from 299 to $403 \mathrm{mg} \mathrm{kg}^{-1}$ in C. rhizophorae, also in the present study. For M. guyanensis, the values of Fe in our study were from 1.057 to $1.690 \mathrm{mg} \mathrm{kg}^{-1}$. Although it does not live in the sediment, but rather adheres to consolidated substrates (mainly in rocky shores), it is observed that high values of Fe were also found in P. perna, both in Guanabara Bay (Lino et al., 2016) and in Santos Bay (Campolim et al., 2018) (Table 3). For Mn, Vilhena et al. (2021) observed an average of $14 \mathrm{mg} \mathrm{kg}^{-1}(\mathrm{dw})$ in $C$. gasar and in the present study we obtained $22.77 \mathrm{mg} \mathrm{kg}^{-1}(\mathrm{dw})$ in this species, values between 15.32 and $26.08 \mathrm{mg} \mathrm{kg}^{-1}(\mathrm{dw})$ in C. rhizophorae and 64.24 and
$102.54 \mathrm{mg} \mathrm{kg}^{-1}$ (dw) in M. guyanensis, therefore, the latter species showed much higher values than those found in oysters. It is possible that the habit of living buried in the sediment (Boehs et al., 2010) provides M. guyanensis with a greater advantage of acquiring $\mathbf{M n}$ from the substrate. Vilhena et al. (2021), observed an average Mn content of $2.020 \mathrm{mg} \mathrm{kg}^{-1}$ (dw) in P. ponderosus in the Pará river (Pará), a species that lives in the sediment. According to Cheng et al. (2013), the sediment is the main source of metals for organisms, which accumulates levels of metals that are higher than those in the water. Oysters such as C. rhizophorae, generally live attached to the aerial parts of mangrove plants (Boehs et al., 2019), having less contact with the soil, which could partly explain these differences in the levels of these elements.

We conclude that the levels of chemical elements investigated indicated, in general, low anthropic impact of estuarine areas of the south/extreme south coast of the state of Bahia, confirming the hypothesis of the present study. The exception was \#5, regarding the presence of As and the high levels of $\mathbf{P b}$ and $\mathbf{C u}$, attributed to the nautical activities in that locality.

\section{Acknowledgements}

The authors would like to thank Julia Benevides and Deise S. Costa, both for their assistance in laboratory processing, to Vinícius H. C. da Silva, for reading the samples at ICP, to Prof. Luiz Roberto M. Pinto, for his guidance on data processing and Ricardo L. Viana, for making the map. To the Fundação de Amparo à Pesquisa do Estado da Bahia - FAPESB for the granting of the scholarship to the first author and to the Comissão Executiva do Plano da Lavoura Cacaueira - CEPLAC, for granting the use of the Soil Laboratory for the digestion of biological samples.

\section{References}

AGENCIA PARA SUSTANCIAS TÓXICAS Y EL REGISTRO DE ENFERMEDADES - ATSDR, 2004. Reseña toxicológica del cobre. Atlanta: Departamento de Salud y Servicios Humanos de EE. UU., Servicio de Salud Pública.

AGENCIA PARA SUSTANCIAS TÓXICAS Y EL REGISTRO DE ENFERMEDADES - ATSDR, 2007a. Toxicological profile for Arsenic (Update). Atlanta: U.S. Department of Health and Human Services. Public Health Service.

AGENCIA PARA SUSTANCIAS TÓXICAS Y EL REGISTRO DE ENFERMEDADES - ATSDR, 2007b, Toxicological profile for lead (Update). Atlanta: U.S. Department of Public Health and Human Services, Public Health Service.

ALMEIDA, E., DIAMANTINO, T. and SOUSA, O., 2007. Breve História das tintas antivegetativas. Corrosão e Protecção de Materiais, vol. 26, no. 01, pp. 6-12.

ANGELI, J.L.F., RUBIO, B., KIM, B.S.M., FERREIRA, P.A.L., SIEGLE, E. and FIGUEIRA, R.C.L., 2019. Environmental changes reflected by sedimentary geochemistry for the last one hundred years of a tropical estuary. Journal of Marine Systems, vol. 189, no. 1, pp. 36-49. http://dx.doi.org/10.1016/j.jmarsys.2018.09.004.

BAKSHI, M., RAM, S.S., GHOSH, S., CHAKRABORTY, A., SUDARSHAN, M. and CHAUDHURI, P., 2017. Micro-spatial variation of elemental 
distribution in estuarine sediment and their accumulation in mangroves of Indian Sudarban. Environmental Monitoring and Assessment, vol. 189, no. 5, pp. 221. http://dx.doi.org/10.1007/ s10661-017-5891-9. PMid:28425071.

BARBOSA, I.S., BRITO, G.B., SANTOS, G.L., SANTOS, L.N., TEIXEIRA L.S.G., ARAUJO, R.G.O. and KORN, M.G.A., 2019. Multivariate data analysis of trace elements in bivalve molluscs: characterization and food safety evaluation. Food Chemistry, vol. 273, no. 01, pp. 64-70. http://dx.doi.org/10.1016/j.foodchem.2018.02.063. PMid:30292376.

BARROS, D. and BARBIERI, E., 2012. Análise da ocorrência de metais: $\mathrm{Ni}, \mathrm{Zn}, \mathrm{Cu}, \mathrm{Pb}$ e Cd em ostras (Crassostrea brasiliana) e sedimentos coletados no Estuário de Cananeia-SP (Brasil). O Mundo da Saúde, vol. 36, no. 4, pp. 635-652. http://dx.doi. org/10.15343/0104-7809.2012364635642.

BOEHS, G., LUZ, M.S.A. and ANDRADE, V.R.D., 2019. Molecular identification of cryptic species of oysters (Genus Crassostrea Sacco, 1897) in the Northeast Atlantic coast of Brazil. Boletim do Instituto de Pesca, vol. 45, no. 2, e446. http://dx.doi. org/10.20950/1678-2305.2019.45.2.446.

BOEHS, G., VILLALBA, A., CEUTA, L.O. and LUZ, J.R., 2010. Parasites of three commercially exploited bivalve mollusc species of the estuarine region of the Cachoeira river (Ilhéus, Bahia, Brazil). Journal of Invertebrate Pathology, vol. 103, no. 1, pp. 43-47. http://dx.doi.org/10.1016/j.jip.2009.10.008. PMid:19850046.

BRAGIGAND, V., BERTHET, B., AMIARD, J.C. and RAINBOW, P.S., 2004. Estimates of trace metal bioavailability to humans ingesting contaminated oysters. Food and Chemical Toxicology, vol. 42, no. 11, pp. 1893-1902. http://dx.doi.org/10.1016/j.fct.2004.07.011. PMid: 15350688

BRASIL. Ministério da Saúde, 1965. Decreto $n^{0} 55.871$ de 26 de março de 1965. Diário Oficial da República Federativa do Brasil, Brasília, 9 abr.

BRASIL. Ministério da Saúde. Agência Nacional da Vigilância Sanitária, 1999. Portaria nº 685 de 27 de agosto de 1998. Diário Oficial da República Federativa do Brasil, Brasília, 1 fev.

BRASIL. Ministério do Meio Ambiente, 2018. Atlas dos Manguezais do Brasil. Brasília: Instituto Chico Mendes de Conservação da Biodiversidade.

BRASIL. Ministério do Meio Ambiente. Conselho Nacional do Meio Ambiente, 2009. Resolução 420 de 28 de dezembro de 2009. Diário Oficial da República Federativa do Brasil, Brasília, 30 dez.

CAGNIN, R.C., QUARESMA, V.S., CHAILLOU, G., FRANCO, T. and BASTOS, A.C., 2017. Arsenic enrichment in sediment on the eastern continental shelf of Brazil. The Science of the Total Environment, vol. 607-608, no. 1, pp. 304-316. http://dx.doi. org/10.1016/j.scitotenv.2017.06.162. PMid:28692900.

CAI, C. and WANG, W.X., 2019. Inter - species difference of copper accumulation in three species of marine mussels: implication for biomonitoring. The Science of the Total Environment, vol. 692, no. 20, pp. 1029-1036. http://dx.doi.org/10.1016/j. scitotenv.2019.07.298. PMid:31539935.

CAMPOLIM, M.B., HENRIQUES, M.B. and BARBIERI, E., 2018. Al, Cd, $\mathrm{Cr}, \mathrm{Cu}, \mathrm{Fe}, \mathrm{Mn}, \mathrm{Ni}, \mathrm{Pb}$ and $\mathrm{Zn}$ in mussels collected in Santos Bay, São Paulo, Brazil: limits required by local legislation. Boletim do Instituto de Pesca, vol. 44, no. 4, pp. 374. http://dx.doi. org/10.20950/1678-2305.2018.44.4.374.

CHARRY, M.P., KEESING, V., COSTELLO, M. and TREMBLAY, L.A., 2018. Assessment of the ecotoxicity of urban estuarine sediment using benthic and pelagic copepod bioassays. PeerJ, vol. 6, no. 1, pp. e4936. http://dx.doi.org/10.7717/peerj.4936. PMid:29868297.

CHENG, Z., MAN, Y.B., NIE, X.P. and WONG, M.H., 2013. Trophic relationships and health risk assessments of trace metals in the aquaculture pond ecosystem of Pearl River Delta, China. Chemosphere, vol. 90, no. 7, pp. 2142-2148. http://dx.doi. org/10.1016/j.chemosphere.2012.11.017. PMid:23219406.

COSTA, L.M., SANTOS, D.C.M.B., HATJE, V., NÓBREGA, J.A. and KORN, M.G.A., 2009. Focused- microwave-assisted acid digestion: evaluation of losses of volatile elements in marine invertebrate samples. Journal of Food Composition and Analysis, vol. 22, no. 3, pp. 238-241. http://dx.doi.org/10.1016/j.jfca.2008.10.017.

DEFOREST, D.K., BRIX, K.V. and ADAMS, W.J., 2007. Assessing metal bioaccumulation in aquatic environments: the inverse relationship between bioaccumulation factors, trophic transfer factors and exposure concentration. Aquatic Toxicology, vol. 84, no. 2, pp. 236-246. http://dx.doi.org/10.1016/j. aquatox.2007.02.022. PMid:17673306.

ENVIRONMENTAL PROTECTION AGENCY - EPA, 1996. Method 3050B: acid digestion of sediments, sludges and soils. Revision 2.

GALTSOFF, P.S., 1964. The American oyster Crassostrea virginica (Gmelin). Fish and Wildlife Service Bulletin, vol. 64, no. 1, pp. 1-16.

GOMES, M.V.T. and SATO, Y., 2011. Avaliação da contaminação por metais pesados em peixes do rio São Francisco à jusante da represa de Três Marias, Minas Gerais, Brasil. Saúde E Ambiente em Revista, vol. 6, no. 1, pp. 24-30.

GÓNGORA-GÓMEZ, A.M., GARCÍA-ULLOA, M., MUÑOZ SEVILLA, N.P., DOMÍNGUEZ-OROZCO, A.L., VILLANUEVA-FONSECA, B.P., HERNÁNDEZ-SEPÚLVEDA, J.A. and ORTEGA IZAGUIRRE, R., 2017. Heavy-metal contents in oysters (Crassostrea gigas) cultivated on the southeastern coast of the Gulf of California, Mexico. Hidrobiológica, vol. 27, no. 02, pp. 219-227. http:// dx.doi.org/10.24275/uam/izt/dcbs/hidro/2017v27n2/Garcia.

HATJE, V., BARROS, F., MAGALHÃES, W., RIATTO, V.B., AMORIM, F.N., FIGUEIREDO, M.B., SPANÓ, S. and CIRANO, M., 2008. Trace metals and benthic macrofauna distributions in Camamu Bay, Brazil: sediment quality prior oil and gas exploration. Marine Pollution Bulletin, vol. 56, no. 2, pp. 363-370. http://dx.doi. org/10.1016/j.marpolbul.2007.10.029. PMid:18062998.

HATJE, V., BÍCEGO, M.C., CARVALHO, G.C. and ANDRADE, J.B., 2009. Baía de Todos os Santos: aspectos oceanográficos. Salvador: EDUFBA.

KIM, B.S.M., SALAROLI, A.B., FERREIRA, P.A.L., SARTORETTO, J.R., MAHIQUES, M.M. and FIGUEIRA, R.C.L., 2016. Spatial distribution and enrichment assessment of heavy metals in surface sediments from Baixada Santista, Southeastern Brazil. Marine Pollution Bulletin, vol. 103, no. 1-2, pp. 333-338. http:// dx.doi.org/10.1016/j.marpolbul.2015.12.041. PMid:26774439.

KIMBROUGH, K.L., JOHNSON, W.E., LAUENSTEIN, G.G., CHRISTENSEN, J.D. and APETI, D.A., 2008. An assessment of two decades of contaminant monitoring in the Nation's Coastal Zone. Silver Spring: NOAA Technical Memorandum NOS NCCOS.

LIMA, T.M. and NEVES, C.A.R., 2016. Sumário mineral 2015. Brasília: Departamento Nacional de Produção Mineral, vol. 35, 135 p.

LINO, A.S., GALVÃO, P.M.A., LONGO, R.T.L., AZEVEDO-SILVA, C.E., DORNELES, P.R., TORRES, J.P.M. and MALM, O., 2016. Metal bioaccumulation in consumed marine bivalves in Southeast Brazilian coast. Journal of Trace Elements in Medicine and Biology, vol. 34, no. 1, pp. 50-55. http://dx.doi.org/10.1016/j. jtemb.2015.12.004. PMid:26854245.

LIU, W.C., LIU, H.M. and KEN, P.J., 2020. Investigating the contaminant transport of heavy metals in estuarine waters. Environmental Monitoring and Assessment, vol. 192, no. 1, pp. 31. http://dx.doi. org/10.1007/s10661-019-8012-0. PMid:31823064.

MELWANI, A.R., GREGORIO, D., JIN, Y., STEPHENSON, M., ICHIKAWA, G., SIEGEL, E., CRANE, D., LAUENSTEIN, G. and DAVIS, J.A., 2014. Mussel watch update: long - term trends in selected 
contaminants from coastal California, 1977 - 2010. Marine Pollution Bulletin, vol. 81, no. 2, pp. 291-302. http://dx.doi. org/10.1016/j.marpolbul.2013.04.025. PMid:23711838.

MIRLEAN, N., MEDEANIC, S., GARCIA, F.A., TRAVASSOS, M.P. and BAISCH, P., 2012. Arsenic enrichment in shelf and coastal sediment of the Brazilian subtropics. Continental Shelf Research, vol. 35, no. 1, pp. 129-136. http://dx.doi.org/10.1016/j. csr.2012.01.006.

MOREIRA, L.B., SASAKI, S.T., TANIGUCHI, S., BÍCEGO, M.C., COSTALOTUFO, L.V. and ABESSA, D.M.S., 2019. Impacts of dredging on biomarkers responses of caged bivalves in a semi-arid region (Ceará State, NE Brazil). Marine Environmental Research, vol. 151, no. 1, pp. 104784. http://dx.doi.org/10.1016/j. marenvres.2019.104784. PMid:31493851.

ONOFRE, C.R.E., CELINO, J.J., NANO, R.M.W. and QUEIROZ, A.F.S., 2007. Biodisponibilidade de metais traços nos sedimentos de manguezais da porção norte da Baía de Todos os Santos, Bahia, Brasil. Revista de Biologia e Ciências da Terra, vol. 7, no. 2, pp. 65-82.

PAN, K. and WANG, W.X., 2009. Biodynamics to explain the difference of copper body concentrations in five marine bivalve species.
Environmental Science E Technology, vol. 43, no. 6, pp. 21372143. http://dx.doi.org/10.1021/es802888u. PMid:19368226.

RAINBOW, P.S., 2002. Trace metal concentrations in aquatic invertebrates: why and so what? Environmental Pollution, vol. 120, no. 3, pp. 497-507. http://dx.doi.org/10.1016/S02697491(02)00238-5. PMid:12442773.

REIMANN, C., MATSCHULLAT, J., BIRKE, M. and SALMINEN, R., 2009. Arsenic distribution in the environment: the effects of scale. Applied Geochemistry, vol. 24, no. 7, pp. 1147-1167. http:// dx.doi.org/10.1016/j.apgeochem.2009.03.013.

SILVA, R.G., SANTOS, R.M., LIMA, M.O., MENDES, L.C.S., MESQUITA, K.F.C. and SANTOS, M.L.S., 2018. Trace elements in oyster farming areas in the Amazon. Boletim do Instituto de Pesca, vol. 44, no. 4, pp. 513-526. http://dx.doi.org/10.20950/16782305.2018.44.4.366.

VILHENA, M.P.S.P., COSTA, M.L., BERRÊDO, J.F., PAIVA, R.S. and MOREIRA, M.Z., 2021. Trace elements and $\delta^{13} \mathrm{C}$ and $\delta^{15} \mathrm{~N}$ isotopes in sediments, phytoplankton and oysters as indicators of anthropogenic activities in estuaries in the Brazilian Amazon. Regional Studies in Marine Science, vol. 41, no. 1, 101618. 